\title{
COMPOST TEAS ARE UNTRADITIONAL BIOAGENTS AGAINST FUNGAL AND BACTERIAL PATHOGENS
}

Ibrahim, Heba A. Kh. ${ }^{1}$ H. Sun ${ }^{2}$; I. H. Ali ${ }^{3}$; Bouthina F. AbdElghany ${ }^{1}$; H. M. El-Khawas ${ }^{3}$ and M. Fayez ${ }^{3}$.

${ }_{1}$ Microbiology Unit, Desert Research Institute, Cairo, Egypt.

2 Division of Earth and Ecosystem Sciences, Desert Research Institute, Las Vegas, Nevada, USA.

3 Department of Agricultural Microbiology, Faculty of Agriculture, Cairo University, Giza, Egypt.

\begin{abstract}
Various compost extracts were experimented for antimicrobial activity against a number of fungal and bacterial candidates. All the compost-borne bacteria isolated from the different composts showed antifungal activity towards seven pathogenic fungal strains, $B$. cinerea and S. cepivorum were the most susceptible. The influence of such bacteria was very limited on five tested bacterial strains. The genome sequencing of compost-borne bacteria showed the probability for the majority of isolates to be Bacillus, besides Brevibacterium, Geobacillus and Streptomyces.

Three different compost teas were evaluated as bioagents against a varity of pathogenic fungi. The antifungal activity of grass tea towards $A$. strictum, $F$. culmorum and $F$. austroamericanum increased with time to reach $100 \%$ after 4 days brewing and decreased thereafter. The antagonistic effect of tamarix tea increased with brewing reaching the maximum at the $2^{\text {nd }}$ day with $S$. cepivorum and $F$. austroamericnaum and after 5 days in case of $A$. strictum and Phyt. cactorum. The lowest antifungal activity of the mixture of mountain mahogany tea of $47 \%$ was recorded with the fungus $P$. expansum after 7 days. The impact of water ratio, dilution rate, heating, autoclaving as well as compost maturity and iron supplement on antifungal activity of compost teas was discussed.
\end{abstract}

Keywords: Compost tea, antifungal activity, antibacterial activity, fungal strains, bacterial strains.

\section{INTRODUCTION}

Synthetic fungicides are extensively used in agriculture worldwide. There are now more than 113 active ingredients registered as fungicides (Knight et al., 1997). Many of these compounds are highly toxic, nonbiodegradable, long-term environmental pollutants, and sometimes carcinogenic for humans and wild animals (Daoubi et al., 2005). In addition, repeated use can lead to loss of efficacy due to pathogen resistance (Daoubi et al., 2005; Russell, 1995).

Composts are considered to be an environmentally safe, agronomically advantageous, and relatively cheap soil organic amendment (Senesi and Brunetti, 1996). Sprays based on compost extracts have been used for hundreds of years with the aim of improving crop yield and quality. There is evidence that the Romans used compost teas and the ancient Egyptians used preparations based on compost or manure extracts as long as 4,000 years ago. Interest in compost extracts and teas waned when pesticides 
Ibrahim, Heba A. Kh. et al.

became available in the $20^{\text {th }}$ century. Sprays based on compost started again in the 1920s (Koepf 1992).

Compost extracts have been used as alternative synthetic fungicides. Composts can provide natural biological control of diseases of roots as well as the foliage of plants. There is a debate over whether compost extracts or compost teas showed be registered with pesticide authorities.

Coping with modern agricultural strategies arising to maintain the environment clean as possible necessitates the adoption of untraditional and new agrobiotechnologies to deal with agricultural pests. Among those, the independable need to minimize the agrochemical input occupies non-tiny place on the map of sustainable agriculture.

The present work emphasizes on securing efficient bio-preprates either organic by-products or microbial formulations capable to alleviate pest invasion ability against farm products.

\section{MATERIALS AND METHODS}

\section{Preparation of composts}

Three composts were prepared from selected waste materials, i.e. grass blended with shredded paper "PG", and two woody plant mulches (tamarix "TS", and mixture of mountain mahogany "MS"). The woody mulches were blended with sewage sludge to optimize $\mathrm{C}$ : $\mathrm{N}$ ratio and moisture level. Composts were made in plastic containers. Aeration was achieved by thorough mixing once every two weeks. The temperature at the center of each was monitored by a thin thermocouple and a Campbell ${ }^{\circledR}$ data logger. Compost $\mathrm{pH}$ was checked, when necessary, and was adjusted to slightly above neutrality using dilute $(1 \%)$ vinegar.

\section{Chemical analysis of composts}

Compost samples were grounded with a Retch Model ZM100 mill using a $1 \mathrm{~mm}$ stainless steel screen and a 24 knife stainless steel rotating head. The ground samples were quantitatively transferred to a large, wide mouth plastic bottle and mixed well before analysis. All analyses (Table 1) were conducted in duplicates. Samples were analyzed by Analytical Services Laboratory, Department of Soil Science, North Carolina State University.

\section{SEM examinations}

The prepared composts were examined for naturally existing microorganisms by scanning electron microscope. Compost samples were soaked in $0.5 \%$ formaldehyde prepared in phosphate buffer solution (PBS) for $15 \mathrm{~min}$, then soaked in $1 \%$ glutaraldehyde in PBS for $15 \mathrm{~min}$, dehydrated in graded ethanol $(15,30,50,75,95,100 \%)$ each for 15 min, followed by two changes in $100 \%$ ethanol, each for $15 \mathrm{~min}$, and two soaks in hexamethyldisilazane (HMDS), each 30 min. Finally HMDS was poured away and samples were air dried in fume hood (Dong et al., 2007).

\section{Compost tea production}

Aerated compost tea was produced by mixing the compost with deionized water in the ratio of $1: 5(\mathrm{w} / \mathrm{v})$ in 2 gallon plastic buckets, and supplemented with $2 \%$ corn syrup to stimulate microbial growth. The entire 
contents were continuously aerated at room temperature with a fish tank pump and bubbling stone. For application, each tea was poured through cheesecloth followed by ultracentrifugation in $11000 \mathrm{rpm}$ for $25 \mathrm{~min}$ at $15^{\circ} \mathrm{C}$, then sterilized by passing through $0.2 \mu \mathrm{m}$ filter and stored in a freezer until use.

\section{Microorganisms tested}

A number of 7 fungal candidates and 4 bacterial strains belonging to various genera were experimented for antifungal and antibacterial activity of compost tea. Those were Acremonium strictum (NRRL 36033), Fusarium culmorum (NRRL 3288), Fusarium austroamericanum (NRRL 2903), Agrobacterium radiobacter (NRRL B-3212), Erwinia uredovora (NRRL B14773) and Ralstonia solanacearum (NRRL B-3212) strains obtained from the Agricultural Research Service (NRRL), Culture Collection, Microbial Genomics \& Bioprocessing Research Unit, National Center for Agriculture Utilization Research, Peoria, Illinois, USA. Botrytis cinerea and Penicillum expansum were isolated by Dr. Chang-Lin Xiao at Washington State University, Tree Fruit Research and Extension Center from decayed apple fruit in central Washington State. Phytophthera cactorum was isolated from silver maple trees in Reno, Nevada. Sclerotium cepivorum was isolated from onion plants in Yerington, Nevada. The E. coli DH10B strain was supplied by New England Biolabs. Fungal strains were maintained on malt extract or potato dextrose media and all bacterial strains maintained in Luria-Bertani (LB) medium at $5^{\circ} \mathrm{C}$ (Atlas, 1995)

\section{Antifungal activity of compost tea}

This assay was quantified as the pathogen growth retardation level was due to addition of compost tea. The following double-strength media appropriate for growing the tested pathogens were prepared. Potato dextrose agar for Sclerotium cepivorum, Phytophthera cactorum, Botrytius cinerea and Penicillum expansum; malt yeast extract agar for Acremonium strictum, Fusarium austroamericanum and Fusarium culmorum. While still luke warm, they were combined with an equal volume of filter-sterilized compost tea, and after thorough mixing, they poured into plates. Four points on plates were inoculated by using a needle and conidia of the test pathogen. At the same time, single strength, compost tea-free medium plates were inoculated in the same manner. Plates were incubated at $28{ }^{\circ} \mathrm{C}$. Incubation was over when colonies reach a substantial size either in the control or in the test plate, which ever came first, and the diameters of the colonies were measured. Antifungal activity in percent was determined against an untreated control (Sun, H. Personal communications).

\section{Antibacterial activity assay}

One $\mathrm{ml}$ compost tea was added to filter discs $(0.8 \mathrm{~cm})$ and allowed to air dry. Discs were placed on LB plate pre-inoculated with $0.1 \mathrm{ml}$ of mid-log phase liquid culture of test bacterium. Plates were incubated at $28{ }^{\circ} \mathrm{C}$ for 2 days, except $E$. coli which was incubated at $37^{\circ} \mathrm{C}$ for 2 days. The zone of inhibition was measured.

\section{Isolation of actinomycetes}

One gram compost was suspended in $9 \mathrm{ml}$ sterile water, vigorously agitated, and heated at $50{ }^{\circ} \mathrm{C}$ for $30 \mathrm{~min}$. Serial dilutions were prepared, and 
Ibrahim, Heba A. Kh. et al.

the different dilutions were plated on $1 / 10$ strength glycerol yeast extract agar supplemented with nystatin $(50 \mu \mathrm{g} / \mathrm{ml})$ and incubated at $27{ }^{\circ} \mathrm{C}$. Distinct actinomycete colonies were picked up and streaked for purity on LB agar (Oskay et al., 2004).

Antifungal activity of actinomycete isolates

The antibiotic-producing actinomycetes were streaked on 1/3 of LB agar plates and incubated at $27^{\circ} \mathrm{C}$ for two days to allow antibiotic production. Fungal pathogen was then stab-inoculated onto the un-used part of the plate in points about three centimeters apart and one centimeter from the actinomycete edge. Incubation resumed, along with reference plates containing the fungus alone, without the actinomycete. After fungal colonies emerged but before they ran out of room to grow, either in the reference or test plate, whichever came first, the assay was performed and the diameters of the colonies were measured. The strength of antifungal activity was calculated by dividing the difference between reference and tested colony diameters by control colony diameters.

Identification of compost-borne bacteria

All compost-borne isolates had genome sequencing at Functional Bioscience, Inc. MGE Innovation Center, University Research Park at Madison, Wisconsin, USA. Phylogenetic and molecular evolutionary analyses were conducted using MEGA version 4 (Tamura et al., 2007).

The compost tea application as a biocontrolling agent was evaluated by two procedures. In the first, the raw compost material was exposed to a) sterilization by autoclaving at $121^{\circ} \mathrm{C}$ for 15 min under $15 \mathrm{psi}$, b) maturity duration and c) water flooding to the ratio of 10:1 (distilled water : organic matter). For the second procedure, the following treatments were applied for the compost tea; a) dilution with distilled water to the tea: water ratios of 1:19, $1: 4,1: 3$ and $1: 1(\mathrm{v} / \mathrm{v}), \mathrm{b})$ heating at $100{ }^{\circ} \mathrm{C}$ for $30 \mathrm{~min}$., c) autoclaving at 121 ${ }^{\circ} \mathrm{C}$ and $15 \mathrm{psi}$ for $15 \mathrm{~min}$ and d) iron supplementation with $1 \mathrm{mM} \mathrm{FeCl}_{3}$.

\section{RESULTS}

\section{Compost temperatures during thermophilic stage}

Temperatures during thermophilic stage in composting of PG and MS composts fluctuated widely as a result of the ambient environment influence. Peak temperature reached $45-50 \stackrel{\circ}{\circ}$, depending upon organic material (Figure 1).

\section{Elemental analysis of composts}

The elemental analysis of the three produced composts showed that $\mathrm{C} / \mathrm{N}$ ratios of $\mathrm{PG}, \mathrm{TS}$ and $\mathrm{MS}$ were 9.6:1, 21.5:1 and 25.2:1 respectively. The PG compost was high in potassium compared to TS and MS, while TS contained the highest sulfur level (Table. 1). 


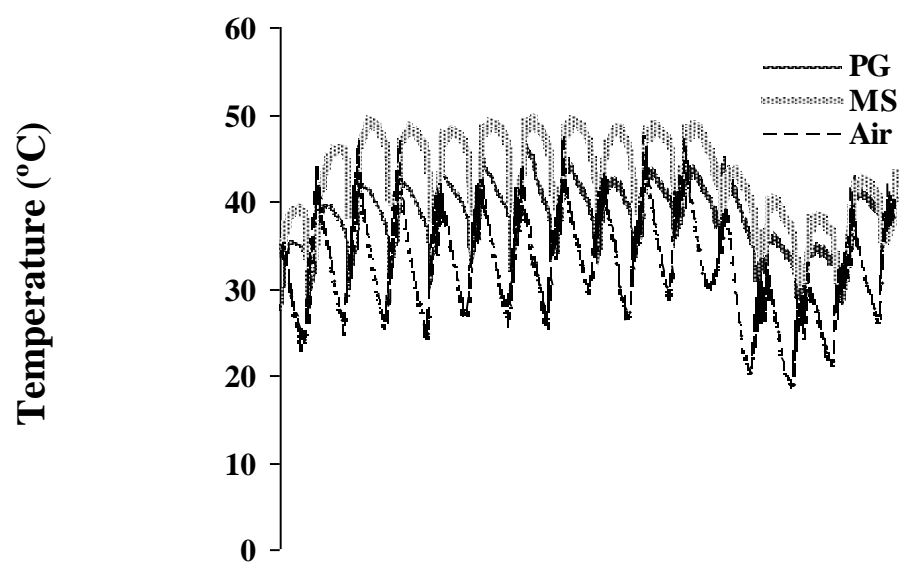

Fig. 1. Temperature profiles during the thermophilic stage of composting (from May 25, 2007 to June 8, 2007).

Table. 1. Major elements in studied composts (\%)

\begin{tabular}{lcccccccc}
\hline Compost & C & N & P & K & Ca & Mg & S & Na \\
\hline PG & 29.8 & 3.1 & 0.7 & 3.2 & 0.4 & 0.8 & 0.9 & 0.3 \\
TS & 35.7 & 1.8 & 0.7 & 0.4 & 2.1 & 0.6 & 1.8 & 0.4 \\
MS & 40.3 & 1.6 & 0.7 & 0.5 & 3.1 & 0.7 & 0.7 & 0.1
\end{tabular}

PG, paper grass compost; TS, Tamarix sludge compost;

MS, mixture of mountain mahogany and sludge compost.

\section{Electron microscopic examination of compost samples}

Scanning electron microscopic examination of $P G$ and $M S$ compost samples showed heavy filamentous growth covering the surface of the organic substances. In PG compost; for example; small cells appeared branched from mycelium (Plate.1.a), such mycelia are form extensive mat (Plate.1.b), and cells occurred in dense like budding with mycelium (Plate.1.c, $\mathrm{d}$, and $\mathrm{e}$ ).

Effect of compost-borne bacteria on growth of fungal pathogens.

All the compost-borne bacteria isolated from the various materials showed antifungal activity against the seven tested pathogenic strains. This effect was bacterial isolate-and pathogenic fungi-dependent (Table 2). The fungus $F$. austroamericanum was the only pathogen that stimulated by bacteria, this was very obvious with isolates $\mathrm{OMN}, \mathrm{G} 72$ and $\mathrm{T} 7$, although this effect was statistically insignificant $(p>0.1)$. Among other fungal members, $B$. cinerea and $S$. cepivorum showed complete lethality due to all the tested bacterial isolates. Other fungal candidates exhibited variable responses to bacterial bioagents. 
Ibrahim, Heba A. Kh. et al.

Plate.1.Scanning electron micrographs for PG compost samples; a and b, filamentous and branching growth pattern; $c$ and d, extensive mycelium covering the surface; e, dense coccoid-shaped forms 
J. Agric. Sci. Mansoura Univ., 33 (7), July, 2008

T2

5289 
Ibrahim, Heba A. Kh. et al.

\section{Effect of compost-borne bacteria on growth of bacterial pathogens}

In general, the antibacterial effect of the compost- borne bacterial isolates on five tested bacterial strains was limited, only $E$ coli showed partial inhibition with $\mathrm{P}, \mathrm{G} 7$, and G71isolates. In contrast, Ralstonia solanacearum was completely inhibited when cultivated with either compost bacterial isolates (Table 3).

\section{Genome sequencing in compost-borne bacteria}

The phylogenetic and molecular evolutionary analyses conducted using MEGA, showed the probability for the majority of isolates to be Bacillus, beside Brevibacterium, Geobacillus and Streptomyces. (Figure 2).

Antibacterial activity of compost tea

The PG compost tea, after brewing for three days, was tested against the five bacterial pathogenic strains. It showed antibacterial activity towards Pseudomonas fluroecences and Erwinia uredovora, but not against E. coli, Ralstonia solanacearum, and Agrobacterium radiobacter .

Disease suppressiveness of compost teas

Three different compost teas were experimented as bioagents against a variety of pathogenic fungi. The disease suppressiveness was expressed as inhibition percentage related to compost-free cultivation medium.

\section{a) Grass compost tea}

At daily seven brewing times, the antifungal activity of grass tea (Figure 3 ) against $A$. strictum, $F$. culmorum and $F$. austroamericanum increased with time to reach $100 \%$ after four days, but decreased thereafter. The compost tea variedly stimulated the growth of $F$. culmorum and $F$. austroamericanum throught the experiment. The activity of such tea against Phyt. cactorum and $S$. cepivorum was apparently different from that with other strains under study. The activity increased to reach $100 \%$ within 2 days and remained constant until the end of the experiment.

b) Tamraix compost tea

Antifungal activity of tamraix tea increased with brewing time with all the tested fungi strains, and did not decrease until the end of the experiment. It reached $100 \%$ after 2 days with $S$. cepivorum and $F$. austroamericanum, and after 3 days with $F$. culmorum, $P$. expansum, and $B$. cinerea., while after 5 days with $A$. strictum and Phyt. cactorum (Figure 4).

\section{c) Mixed compost tea}

Figure (5) shows that the activity of MS tea increased with time for all seven tested strains, and this activity did not decrease until the end of the experiment. The lowest antifungal activity was $47 \%$ with fungus $P$. expansum after 7 days, while with all other strains the activity reached $100 \%$ but at different times. 
J. Agric. Sci. Mansoura Univ., 33 (7), July, 2008

T3

5291 
Ibrahim, Heba A. Kh. et al.

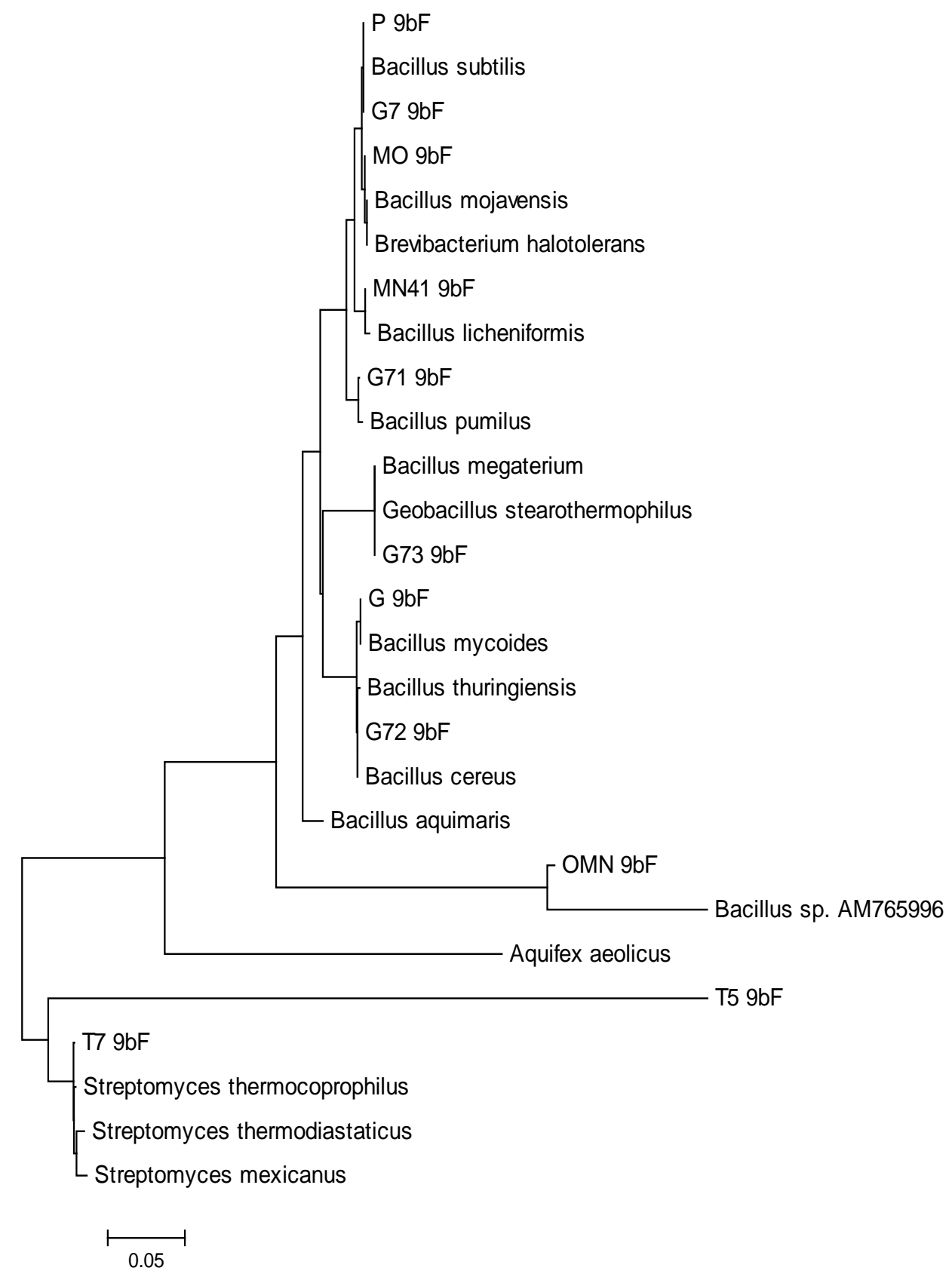

Fig. 2.The phylogenetic and molecular evolutionary analyses of compost-born bacteria. 
J. Agric. Sci. Mansoura Univ., 33 (7), July, 2008

Brewing duration (day)

Fig. 3. Antifungal activity as a function of brew duration of $P G$ compost (error bar = STDEV; $n=3-12$ ). 
Ibrahim, Heba A. Kh. et al.

Fig. 4. Antifungal activity as a function of brew duration in TS compost tea.

(error bar = STDEV; $\mathrm{n}=9-12$ ). 
J. Agric. Sci. Mansoura Univ., 33 (7), July, 2008

\section{Brewing duration (day)}

Fig. 5. Antifungal activity as a function of brew duration in MS compost tea.

(error bar = STDEV; $\mathrm{n}=$ 9-12). 
Ibrahim, Heba A. Kh. et al.

\section{Factors affecting the antifungal activity of compost tea}

\section{a) Water ratio}

During making compost tea, the water to compost ratio was 5 to $1(\mathrm{v} / \mathrm{w})$.With this ratio, the activity of $\mathrm{PG}$ and TS compost teas against Sclerotium cepivorum reached the maximum (100\%) after 2 days and did not change until the end of the experiment. With water to compost ratio of 10 to 1 , the activity reached the maximum after 2 days with $P G$ tea, and after 1 day with TS tea, but decreased thereafter for both (Figures 6 and 7).

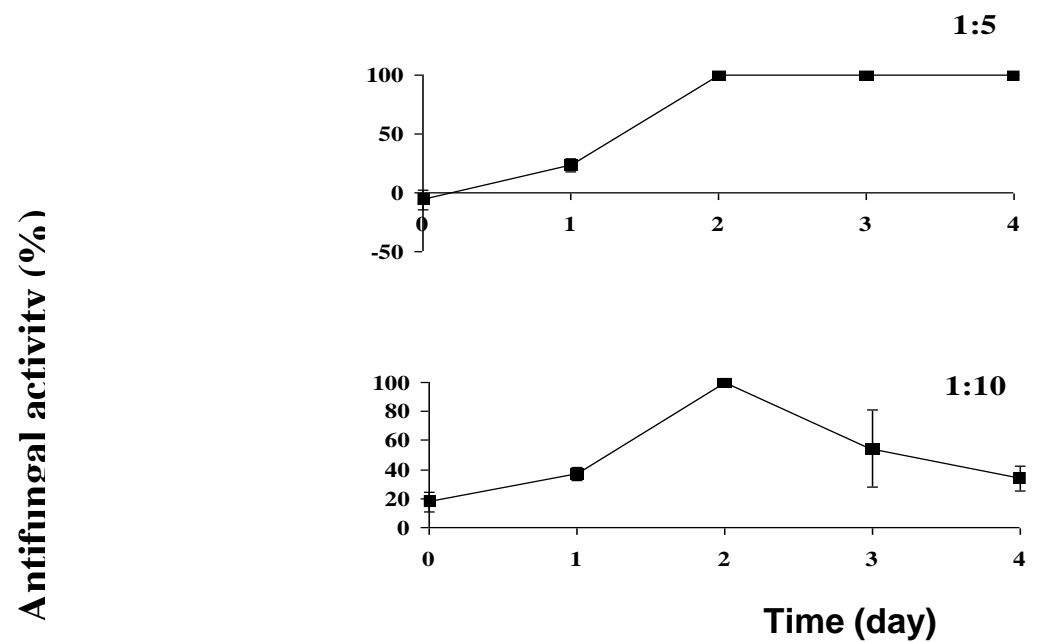

Fig. 6. Effect of compost to water ratio on antifungal activity of PG compost tea against Sclerotium cepivorum

(error bar $=$ STDEV; $n=3$ ).

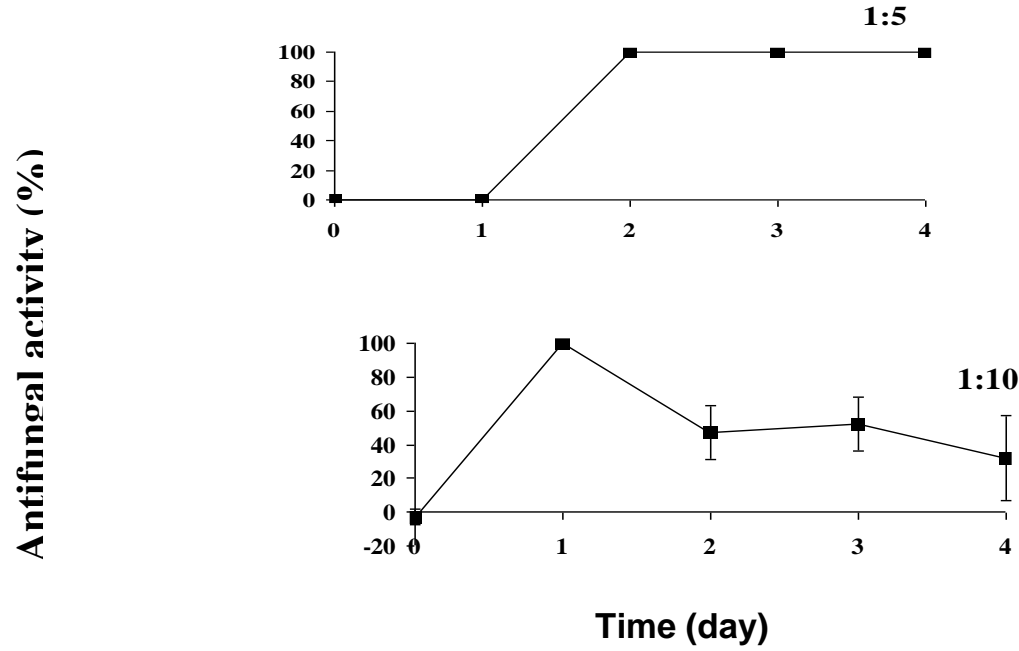

Fig. 7. Effect of compost to water ratio on antifungal activity of TS compost tea against Sclerotium cepivorum

(error bar $=$ STDEV; $\mathrm{n}=3$ ). 


\section{b) Dilution rate}

In all the brewing time experiments, the ratio of compost tea to water was $1: 1$; this ratio gave $100 \%$ inhibition after three days of brewing for $P G$ compost tea against Phyt. cactorum and S. cepivorum. With higher dilutions, the activity of PG tea after three days did not change. With S. cepivorum, the activity was the same even with 1:19 ratio; while with Phytophthera cactorum, the activity did not change up to $1: 4$ ratio, but decreased to reach $73 \%$ at $1: 19$ dilution rate.

\section{c) Heating of compost tea}

Heating at $100^{\circ}$ for 30 min decreased the activity of PG compost tea against $P$. expansum, and hadno effect on antifungal activity of TS and MS teas against $A$. strictum and $S$. cepivorum or TS tea against $P$. expansum, but decreased the activity of MS against $P$. expansum .

\section{d) Autoclaving}

The grass compost tea, after three days brewing, then added to water at ratio 1:3, inhibited the growth of Phyt. cactorum and S. cepivorum. But after autoclaving, the activity against Phyt. cactorum decreased to be $61 \%$, while did not change against $S$. cepivorum.

\section{e) Compost autoclaving}

Sterilization of PG, TS and MS composts before making compost teas did not change the antifungal activity of any material against $A$. strictum or $S$. cepivorum, but all teas from the three composts lost parts of their activities against $P$. expansum .

\section{f) Compost maturity}

The maturity of compost materials is among the criteria that determine their ability to suppress plant pathogens. Therefore, a part of this study has been dealt with the various compost teas when being matured or immature. Out of seven fungal pathogens, this expermint was limited to Phytophthera cactorum and $S$. cepivorum. While the immature PG compost slightly activated the growth of Phytophthera cactorum, an antifungal activity of $72 \%$ was occurred with the fungus $S$. cepivorum. Maturation of the organic materials did magnify their antifungal activity; this resulted in suppression percentages of $100 \%$ towards both fungal strains.

In case of MS compost tea, the immature and matured states obviously inhibited the fungal growth with antifungal activity ranging from 56$100 \%$. The deleterious effects were, in general, more pronounced against Phyt.cactorum.

Similarly, the MS compost teas did affect the survival of fungal candidates. The fungus $S$. cepivorum deemed more susceptible to both matured and immature organic materials than the other microbial member. The former microorganisms did injure to higher extent when exposed to the matured compost than the immature one.

g) Iron supplement

The susceptibility of pathogenic members to various compost teas of different natures was evaluated when the latter materials were amended with $1 \mathrm{mM}$ of $\mathrm{FeCl}_{3}$. This concentration of iron as The iron concentration of $1 \mathrm{mM}$ $\mathrm{FeCl}_{3}$ did markedly stimulate the growth of either $B$. cinerea, Phyt. cactorum or S. cepivorum. On the contrary, F. austroamericanum and F. culmorum 
Ibrahim, Heba A. Kh. et al.

obviously harmed due to iron application, respective antifungal activities of 42 and $48 \%$ related to control were record. Both $A$. strictum and Pen. expansum did not respond to iron presence in cultivation medium.

The iron-received PG compost tea seemed to have no conspicuous influence on the majority of pathogenic fungi tested. The strongly inhibited strains were $P$. expansum and Phyt. cactorum .No appearant antibiosis towards all the tested fungi was attributed to TS compost tea supplied with $1 \mathrm{mM} \mathrm{FeCl}$. While very little deleterious influence of iron containing Ms compost tea against the fungus $P$. expansum, other pathogenic members did successfully withstand the $\mathrm{FeCl}_{3}$-enriched compost.

\section{DISCUSSION}

The promotion of environmental management and the mission of sustainable development have exerted ever-increasing pressure demanding for the adoption of proper methods to protect the environment across environmental-unfriendly activities. As mentioned by Tam and Tam (2005), three main wastes minimization strategies of reuse, recycle and reduction are collectively called the "3Rs".

Recycling, being among the strategies in waste minimization, offers three benefits; 1) reduce the demand upon new resources, 2) cut down on transport and energy production costs and 3) use wastes which would otherwise be lost to landfill sites (Edwards, 1999). To improve the practices of waste recycling, the present work focuses on monitoring the antimicrobial activity of a number of compost teas against representative fungal and bacterial candidates.

Compost tea refers to the aqueous extract of compost after fermentation in water (Brinton et al., 996, Scheuerell and Mahaffee, 2002; Litterick et al., 2004b). Compost tea produced by recirculating water through composting with intention of maintaining aerobic conditions is termed" aerated compost tea" and " organic tea"(Riggle,1996) while tea produced without stirring is called non aerated compost tea .

Compost teas might be applied as a foliar spray or through irrigation systems to provide nutrients and suppress plant diseases. In general, such teas contain long chain carbon molecules which provide carbon and oxygen for soil microorganisms, especially myccorrhizal fungi, that live on or in plant roots and can increase the plant's ability to absorb water and nutrients. With using compost tea, it is possible to form a protective barrier around plant roots which helps to control nematodes and disease organisms (Grobe, 1997). Nutrients exist in teas could be used by soil microorganisms and plants. The microbes naturally present in teas might be competitive with soil microbes, but have the opportunity to become a part of the soil and rhizosphere microbial community (Bess, 2000).

The present work provides original information on the possible contribution of compost tea in the integrated pest management programs. This has been done via recycling of a number of natural organic wastes collected from Nevada State, USA. Those were grass blended with shredded 
paper besides two woody plant mulches (tamarix and a mixture of mountain mahogany). In a number of short-term incubation experiments, the antibiosis of compost teas towards some fungal and bacterial pathogens was evaluated.

Results provide unequivocal evidence that the antifungal substances in compost teas were produced during brewing. The compost teas prepared from the different in-put materials had widely different suppression effects. The differences in properties of these substances are in relation to beneficial and pathogenic organisms (de Brito Alvarez et al., 1995; Aryantha et al., 2000). Baker and Cook (1974) suggested that there are two general categories for suppression mechanisms, general and specific. The general applies where disease suppression is attributed to the activity of many different types of microorganisms, for example, Phytophthera (Hoitink et al., 1997). While specific applies when disease suppression occurs by just one or two microorganisms, that produce antibiotics or those induce systemic resistance in plants (to specific pathogen) (Litterick et al., 2004a). Examples of pathogens suppressed in the specific way include Rhizoctonia solani, Sclerotium rolfsii and Sclerotinia sclerotium (Jones and Watson, 1969; Chung and Hoitink, 1990; Gorodecki and Hadar, 1990; McQuilken et al., 2003). Multple modes of actions are involved in suppression of plant disease with compost tea. This depends on the diverse of microbial community in compost teas.

El-Masry et al. (2002) state that compost extracts did not contain antibiotics or siderophores, even they were suppressive to soil-borne pathogens. These results indicate that, in these instances, the suppressive effect was predominantly biological rather than chemical or physical in nature (Noble and Coventry, 2005).But Weltzien (1991) mentioned that the number and the quality of living microorganisms in the compost teas are largely but not exclusively, responsible for disease suppression.

In all our experiments, the antifungal activities increased with brewing time. This possibly means, the longer the brewing time, the greater the amount of soluble materials extracted from the compost in teas as food resource for beneficial bacteria and fungi (Ingham, 2000), which produce antimicrobial compounds. Brewing beyond the optimum time will lead microorganisms to run out of food and may begin to decline or die. Here, Weltzien (1991) concluded that the inhibitory substances accumulate when extraction times are extending, and may add to the suppression capacity. The decline in the antifungal activity after few days reflects that compost tea as a fungicide of microbial origin, synthesized biologically, is inherently biodegradable. But our data should be attributed with caution because the teas are possibly containing concentrations exceeding the minimum dosages required to stop pathogen growth. Kai et al. (1990) suggested that the antifungal agents in bark-compost extract might be lipid in nature, relatively low polar compounds, and had heat stable structure. Also, Stindt (1990) found that longer extraction times result in a more stable biological activity, and Weltzien (1991) stated that sterile filtration had low effect on the activity of the extract. But most of previous studies indicated that heating of tea 
Ibrahim, Heba A. Kh. et al.

negated suppression (Ketterer, 1990: Tranker, 1992; Scheuerell and Mahaffee, 2004).

It is well known that most of the antibiotics are produced by actinomycetes. Indeed, we found them abundant in our compost materials. In addition, we isolated some of actinomycetes and they showed to secret compounds able to suppress the growth of the fungal pathogens we tested with tea. Furthermore some of these are able to suppress some bacterial pathogens .Contrary to the high antifungal activity of the teas in our study, no inhibitory effect, except few cases, and no growth-stimulation was shown against bacteria. There might be a parallel between this selective antimicrobial activity of the teas and the formation of the "bacterial type" microflora of the compost which plays the major role in suppression (Hashimoto, 1977).

The antimicrobial activity of compost teas are expected to be influenced by several factors. Therefore, it was decided to experiment the effect of water ratio, dilution rate, heating, autoclaving, compost autoclaving, compost maturity and iron supplement on the capacity of teas to suppress the microbial pathogens.

The ratio of water to compost might influence the rate of oxygen depletion during making compost tea (Cronin et al., 1996). In all our experiments, the ratio of water to compost was 5: 1.Weltzien (1990) found that no difference in suppression for water: compost ratios between 1:3 and $1: 10$. This is in disagreement with our work because with ratio $1: 10$ the suppression effect decreased after 3 days comparing with ratio 5:1 wich maintained at the maximum (100\%) until the end of the experiment (4 days). Also, Welke (2004) stated that the effect of $4: 1$ and $8: 1$ ratios on the incidence of $B$. cinerea had a similar effect. Elad and Shtienberg (1994) and Cronin et al. (1996) found that very concentrated extracts of compost teas reduced disease incidence dramatically. In our experiments, the ratio of compost tea to water of $1: 1$ gave $100 \%$ inhibition in most cases, while with higher dilutions ( up to 1:19), the activity did not change with almost all tested fungal pathogens except with Phytophthera cactorum, where reduction approximated $73 \%$. These results are in agreement with those of Elad and Shtienberg (1994), who found that a fivefold dilution of cattle manure extract was ineffective, whereas similar dilution of chicken-cattle manure and grape marc extracts resulted in a significant reduction in the disease. Also, Scheuerell and Mahaffee (2004) found that diluting compost tea 1:9 (v/v) with tap water significantly reduced disease suppression in five of six trials, with intermediate dilution rates having variable reduction in suppression.

Tränkner (1992) reviewed German studies that claim composts should be two to six months old when selected for use. Compost maturity in our work did influence the suppression activity of all compost teas against all tested fungal pathogens. Immature compost decreased the suppression effect of compost teas. This is in agreement with the work of Tuitert and Bollen (1990), who repoted that amendment of $20 \%$ long matured compost suppressed $R$. solani, whereas amendment of shortly matured compost (32 days) did not. This is in contrast to the fining of Al-Dahmani et al. (2003); they found that compost tea prepared from compost cured in windrows for $3,5,10$ or 10 
months significantly reduced the severity of bacterial spot caused by Xanthomonas vesicotoria.

Compost autoclaving as a factor to determine the antibiosis as a mechanism of suppression was investigated in the present work. Sterilization of composts before making compost teas did not change the antifungal activity of any material against $A$. strictum or $S$. cepivorum, but all teas from the three composts lost parts of their activities against $P$. expansum. Apparently, such suppression is due to the presence of heat-resistant and heat-labial chemical inhibitors occurring, and some antibiotic metabolites present in compost tea originate from the compost source. Scheuerell and Mahaffee (2002) stated that when compost was sterilized and then fermented, no suppressive activity was found. In our work, heating at $100^{\circ} \mathrm{C}$ for $30 \mathrm{~min}$ or autoclaving of compost tea at $121^{\circ} \mathrm{C}$ for $15 \mathrm{~min}$ reduced the suppression effect of teas in some cases but not in others. Activity of extracts after filtration or autoclaving revealed that biocontrol agents possibly present in the unfiltered extracts were not essential to compost tea efficacy. This is in agreeing with. Elad and Shtienberg (1994), who mentioned that control of grey mould induced by pasteurized compost water extracts did not differ significantly from that of unheated compost water extracts. Whereas all unheated extracts reduced disease significantly, compared with the untreated control, in one case pasteurized extracts (grape marc) failed to suppress disease on pepper significantly relative to the control. Stindt (1990) found that increasing temperature from 20 to $95^{\circ} \mathrm{C}$ in water bath for $30 \mathrm{~min}$ clearly reduced the extract efficacy, and treatment at $95^{\circ} \mathrm{C}$ resulted in almost complete removal of the inhibitory effects. Also Scheuerell and Mahaffee (2004) reported that heating of compost tea to 95 to $98{ }^{\circ} \mathrm{C}$ for $30 \mathrm{~min}$ and cooling to $25^{\circ} \mathrm{C}$ before drenching significantly increased damping-off compared with that of unheated compost tea. McQuilken et al. (1994) and Cronin et al. (1996) stated that autoclaved extracts decreased or lost activity completely comparing with untreated extracts.

Siderophores can act as growth factors and some as powerful antibiotics (Neilands, 1981). Some studies suggested that the microorganisms present in teas produce siderophores, which sequester iron, and making it unavailable to the pathogens. In our work, there was no conspicuous influence on the majority of pathogenic fungi tested by adding $\mathrm{FeCl}_{3}$ to the three tested compost teas, while very little deleterious influence of iron containing compost tea against $P$. expansum and Phyt. cactorum appeared. Dianez et al. (2006) reported that the addition of $1 \mathrm{mM}$ of $\mathrm{FeCl}_{3}$ deactivated the siderophores present in grape marc compost tea, suppressing their inhibition of fungal development.

In conclusion, the findings of the present study authenticate the validity of compost tea as a bioagent. To maximize the antibiosis ability of such product, it is strongly recommended to use it in combination with other microbial formulations capable to antagonize plant pathogens. 


\section{REFERENCES}

Al-Dahmani, J. H.; Abbasi, P. A.; Miller, S. A. and Hoitink, H. A. J. (2003). Suppression of bacterial spot of tomato with foliar sprays of compost extracts under greenhouse and field conditions. Plant Dis., 87:913-919.

Aryantha, I. P.; Cross, R. and Guest, D. I. (2000). Suppression of Phytophthora cinnamomi in potting mixes amended with uncomposted and composted animal manures. Phytopathology, 90 (7): 775-782. Cited by Litterick et al. (2004).

Atlas, R. M. ( 1995). Handbook of media for environmental microbiology. CRC Press Inc. New York, New York

Baker, K. F. and Cook, R. J. (1974). Biological control of plant pathogens. In: "The Biology of Plant Pathogens". (Eds. Kelman, A. and Sequira, L.,), W. H. Freeman and Co., San Francisco. p. 220-285. Cited by Litterick et al. (2004).

Bess, V. H. (2000). Understanding compost tea. Biocycle, 41(10): 71-72.

Brinton, W. F., Trankner, A., and Droffner, M. (1996). Investigations into Liquid Compost Extracts. Biocycle, 37:68-70.

Chung, Y. R. and Hoitink, H. A. J. (1990). Interactions between thermophilic fungi and Trichoderma hamatum in suppression of Rhizoctonia damping-off in a bark compost-amended container medium. Phytopathology, 80: 73-77. Cited by Litterick et al. (2004a).

Cronin, M.J.; Yohalem, D.S.; Harris, R.F. and Andrews, J. H. (1996). Putative mechanism and dynamics of inhibition of the apple scab pathogen Venturia inequalis by Compost Extracts. Soil Biology \& Biochemistry, 28(9):1241-1249.

Daoubi, M.; R. Hernandez-Galan; A. Benharref; and Collado, I. G. (2005). Screening study of lead compounds for natural product-based fungicides: antifungal activity and biotransformation of 6alpha, 7alphadihydroxy-betahimachalene by Botrytis cinerea. J. Agric. Food Chem., 53:6673-6677.

de Brito Alvarez, M. A.; Gagn'e, S. and Antoun, H. (1995). Effect of compost on rhizosphere microflora of the tomato and on the incidence of plant growth promoting Rhizobacteria. Appl. Environ. Microbiol. 61: 194199. Cited by Litterick et al. (2004a).

Dianez, F.; Santos, M.; Boix, A.; de Cara, M.; Trillas, I.; Avilés, M.; and Tello, J. C. (2006). Grape Marc compost tea suppressiveness to plant pathogenic fungi: role of siderophores. Compost Scien. and Utiliz, 14(1) 48-53.

Dong, H.; Rech, J. A.; Jiang, H.; Sun, H. and Buck, B. J. (2007). Endolithic cyanobacteria in soil gypsum: Occurrences in Atacama (Chile), Mojave (United States), and Al-Jafr Basin (Jordan) Deserts, J. Geophys. Res., 112, G02030, doi:10.1029/2006JG000385.

Edwards, B. (1999). Sustainable Architecture. European directives and building desigen, $2^{\text {nd }}$ ed. Oxford. Architectural Press.

Elad, Y. and Shtienberg, D. (1994). Effect of compost water extracts on grey mould (Botryties cinerea). Crop-prot., 13(2):109-114. 
El-Masry, M.H.; Khalil, A.I.; Hassouna, M.S.; Ibrahim, H.A.H. (2002). In situ and in vivo suppressive effect of agricultural composts and their water extracts on some phytopathogenic fungi. World Journal of Microbiology \& Biotechnology, 18:551- 558.

Gorodecki, B. and Hadar, Y. (1990). Suppression of Rhizoctonia solani and Sclerotium rolfsii in container media containing composted separated cattle manure and composted grape marc. Crop Protection, 9:271-274. Cited by Noble and Coventry (2005)

Grobe, Karin (1997). It's a new era for farm compost. BioCycle, 38 (5) 52.

Hashimoto, H. (1977). Theory and Application of Organic Soil Amendment. Noubunkyou.Tokyo (in Japanese) p. 259 Cited by Kai et al. (1990).

Hoitink, H. A. J.; Stone, A. G. and Han, D.Y. (1997). Suppression of plant disease by composts. HortScience, 32:184- 187.

Ingham, E.R. (2000). The Compost Tea Brewing Manual. Unisun Communications, Corvallis, Oregon.171pp.

Jones, D. and Watson, D. (1969). Parasitism and lysis by soil fungi of Sclerotinia sclerotiorum (Lib.) de Bary, a phytopathogenic fungus. Nature, 224: 287-288. Cited in Litterick et al. (2004).

Kai, Hideaki, Tohru Ueda, and Masahiro Sakaguchi. (1990). Antimicrobial activity of bark-compost extracts. Soil Biol. Biochem., 22 (7): 983-986.

Ketterer, N. (1990). Untersuchungen Zur Wirkung von Kompost-Extraken auf den Blattbefall ser kartoffel und Tomate durch Phytophthera infestans sowie auf den befall der weinrebe durch Plasmospora viticola, Pseudopziza und Uncinula necator. Dissertation. Univ. of Bonn. Cited by Scheuerell and Mahaffee (2002).

Knight, S. C.;Anthony, V. M.; Brady, A. M.; Greenland, A. J.; Heaney,S. P.; Murray, D. C.; Powell, K. A.; Schulz, M. A.; Spinks, C. A.; Worthington, P. A. and Youle, D. (1997). Rationale and perspectives on the development of fungicides. Annu. Rev. Phytopathol., 35:349-372.

Koepf, H. H. (1992). Biodynamic farming: Principles and practice. Anthro. Press, New York. Cited by Scheuerell and Mahaffee (2002).

Litterick, A. M.; Harrier, L.; Wallace, P.; Watson, C. A. and Wood, M. (2004a). The role of uncomposted materials, composts, manures, and compost extracts in reducing pest and disease incidence and severity in sustainable temperate agricultural and horticultural crop production - A Review. Critical Rev. of Plant Scien, 23(6): 453-479.

Litterick, A. M.; Watson, C.A.; Wallace, P. and Wood, M. (2004b). Compost teas - a simple disease control solution for organic crops. In: "Organic farming: science and practice for profitable livestock and cropping". (Ed. A. Hopkins). Newport, Shropshire, UK. p. 188-191.

McQuilken, M. P.; Whipps, J. M. and Lynch, J. M. (1994). Effects of Water Extracts of Composted Manure-Straw Mixture on the Plant Pathogen Botrytis cinerea. World J. Microbiol. Biotech., 10:20-26.

Neilands, J.B. (1981). Microbial iron compounds. Ann Rev Biochem 50:715731.Cited by Diánez et al. (2006).

Noble, R. and Coventry, E. (2005). Suppression of soil-borne plant diseases with composts: a review. Biocontrol Science and Technology, 15:3-20. 
Oskay, M.; Tamer, A. Ü. And Azeri, C. (2004). Antibacterial activity of some actinomycetes isolated from farming soils of Turky. African Journal of Biotechnology, 3(9):441-446.

Riggle, D. (1996). Compost teas in agriculture. Biocycle, 37:65-67.

Russell, P. (1995). Fungicide resistance: occurrence and management. J. Agric. Sci., 124:317-323.

Scheuerell, S. J. and Mahaffee,W. F. (2002). Compost tea: Principles and prospects for plant disease control. Compost Sci. Utilization 10: 313338.

Scheuerell, S. J. and Mahaffee, W. F. (2004). Compost tea as a container medium drench for suppressing seedling damping-off caused by Pythium ultimum. Phytopathology, 94:1156- 1163.

Senesi, N. and Brunetti, G. (1996). Chemical and physico-chemical parameters for quality evaluation of humic substances produced during composting. In "The Science of Composting". (De Berttoldi, M.; Sequi, P.; Lemmes, T. and Pappi, T.) Chapman and Hall, London, UK. ISBN 0751403830. Part 1 ed. p. $195-212$.

Stindt, A. (1990). Untersuchungen zur wirkung und zu den wirkungsmechanismen von kompostextrakten auf Botrytis cinerea Pre. Ex Nocca and Balb an Erdbeeren, Kopfsalat und buschbohnen. Disseration Univ. of Bonn. Cited by Weltzien (991).

Tam, W. Y. Vivian and Tam, C. M. (2005). Evaluation of existing waste recycling methods: A Hong Kong study. Buil. Environ (In press).

Tamura K, Dudley J, Nei M \& Kumar S (2007) MEGA4: Molecular Evolutionary Genetics Analysis (MEGA) software version 4.0. Molecular Biology and Evolution 24:1596-1599. (Publication PDF http://www.kumarlab.net/publications)

Trankner, Andreas. (1992). Use of agricultural and municipal organic wastes to develop suppressiveness to plant pathogens. In: "Biological Control of Plant Diseases". (Eds. E.C. Tjamos, G.C. Papavizas, and R.J. Cook). NATO ASI Series No. 230. Plenum Press, New York, NY. p. 35-42.

Tuitert, G. and Bollen, G.J. (1996). The effects of composted vegetable, fruit and garden wastes on the incidence of soilborne plant diseases. In: "The Science of Composting "(editors. De Bertoldi M, Sequi P, Lemmes B, Papi T,). London: Blackie Academic \& Professional. P.1365-1369.

Welke, S. E. (2004). The effect of compost extract on the yield of strawberries and the severity of Botyrtis cinerea. J. Sust. Agric., 25:5768.

Weltzien, H. C. (1990). The use of composted materials for leaf disease suppression in field crops. Monograph. Br. Crop. Prot. Counc., 45:115120. Cited by Scheuerell and Mahaffee (2002).

Weltzien, H. C. (1991). Biocontrol of foliar fungal disease with compost extracts. Microbial Ecology of Leaves. J. H. Andrews and S. S. Hirano, eds. Springer- Verlag, New York. p. 430-450 
شــاى الكمبوسـت عوامـل حيويـة غيـر تقليديـة فـى مكافــة اللفطريـات والبكتريـا

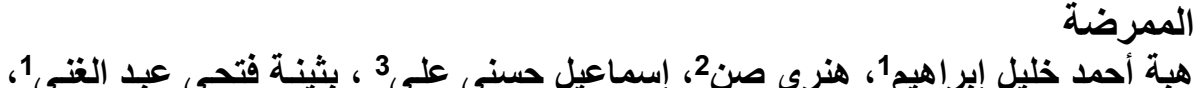

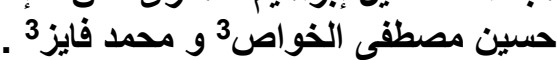

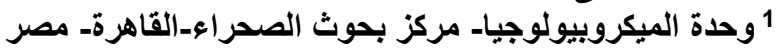
2 3 قسم الميكروبيولوجيا-كلية الزراعة_الجامعة القاهرة

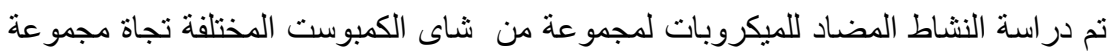

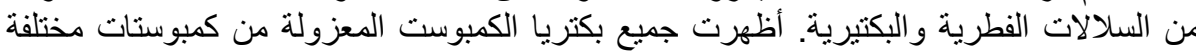

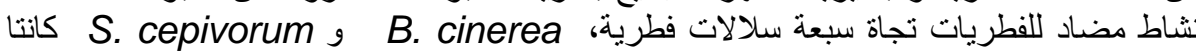
أكثر السلالات نأثر ا بينما كان التأثير على الخمس سلالات التات البكتيرية المختبرة الأخرى محدود للغاية.

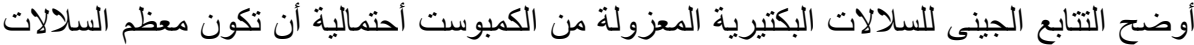

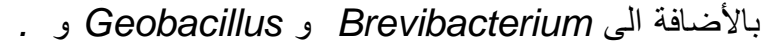

Bacillus

Streptomyces

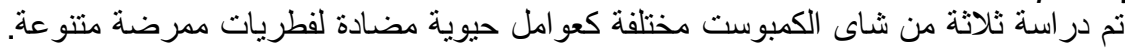

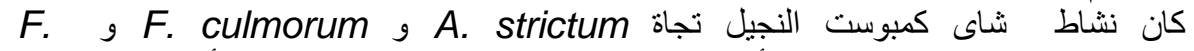
نaustroamericanum في أزدياد مع الزمن ليصل الى 100\% بعد 4 أيام من التخمير ثم

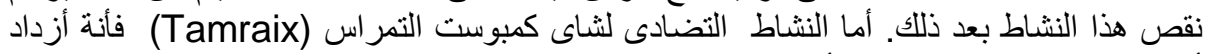

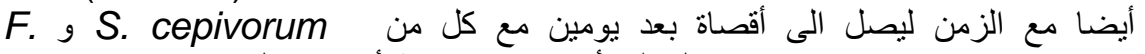

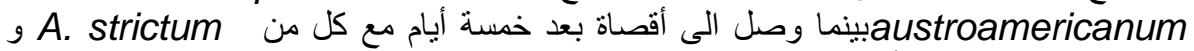

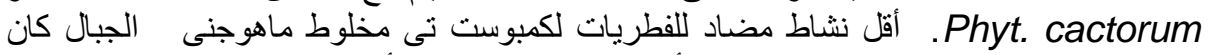

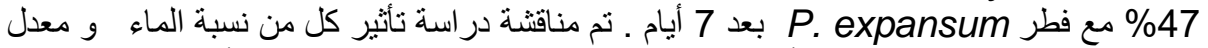

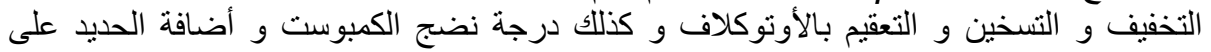

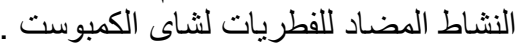


Ibrahim, Heba A. Kh. et al.
$\begin{array}{lllllllllll}5284 & 5285 & 5286 & 5287 & 5288 & 5289 & 5290 & 5291 & 5292 & 5293 & 5294\end{array}$

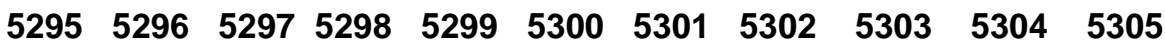

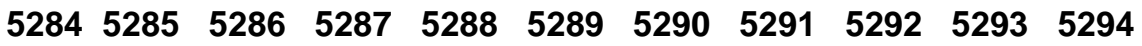

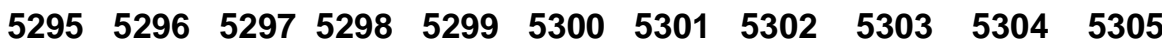

